\title{
Insulin receptor binding and tyrosine kinase activity in liver and skeletal muscle from fasted rats
}

\author{
M. Balage, C. Sornet, M. Manin and J. Grizard
}

INRA Clermont-Ferrand-Theix, laboratoire d'étude du métabolisme azoté et CNRS UA 041123, 63122 Ceyrat, France

(14th meeting of the INRA Development Group, Clermont-Ferrand, 25-27 May 1988)

Summary - Insulin binding and tyrosine kinase activity of the insulin receptor have been measured in the liver and muscles of rats fed or submitted to a 72-h-fasting. In both tissues, insulin binding increased in fasting rats. In liver, the ability of insulin to simulate receptor tyrosine kinase activity greatly unpaired during fasting, but remained unchanged in muscle. The change during fasting of the insulin-stimulated tyrosine kinase activity of the insulin receptor is specific to certain tissue.

insulin — receptor — tyrosine kinase activity — rat — fasting

Résumé - Récepteurs d'insuline et activité tyrosine kinase dans le foie et le muscle du rat en crolssance : influence d'un jeûne de $72 \mathrm{~h}$. La fixation d'insuline et l'activité tyrosine kinase du récepteur ont été mesurées dans le foie et le muscle squelettique (préparations de membranes microsomiales solubilisées et purifiées par chromatographie d'affinité) du rat nourri ou soumis à un jeûne de $72 \mathrm{~h}$. Dans les deux tissus, la fixation d'insuline est augmentée chez les rats soumis au jeûne. Dans le foie, la capacité de l'insuline à stimuler l'activité tyrosine kinase du récepteur est fortement diminuée au cours du jeûne alors qu'elle est inchangée dans le muscle. La variation de réponse à l'insuline de l'activité tyrosine kinase du récepteur induite par le jeûne présente donc une spécificité tissulaire.

insuline — récepteur — tyrosine-kinase — rat - jeûne 


\section{INTRODUCTION}

Fasting has been shown to alter insulin action in vivo, i.e., there was an impairment in insulin responsiveness in both glucose utilization and production in rats (Penicaud et al., 1985). In vitro, insulin responsiveness was also impaired in liver (Cech et al., 1980), but not in muscle (Brady et al., 1981). Thus, in order to clarify the role of insulin receptor interaction in the regulation of insulin action during starvation, we measured insulin binding and insulin receptor tyrosine kinase activity in both liver and skeletal muscle of 72-h-fasted rats.

\section{ANIMALS AND TREATMENTS}

Male Wistar rats $(150 \mathrm{~g})$, housed in controlled environmental conditions $\left(22{ }^{\circ} \mathrm{C}\right.$, $60 \%$ relative humidity and $12 \mathrm{~h}$ dark period) were either fed ad libitum a standard rat chow or fasted for $72 \mathrm{~h}$. Livers and skeletal muscles from hind legs were removed, and kept at $-80^{\circ} \mathrm{C}$ until use. Insulin receptors (microsomal membranes) were then prepared, according to standard methods of Havrankova, Roth and Browstein (1978) and Hedo et al. (1981). Insulin binding and insulin receptor tyrosine $\mathrm{kj}$ nase activity (assessed by the ability of insulin to stimulate the phosphorylation of the artificial exogenous substrate poly GluTyr 4:1) were measured in partially wheat germ agglutinin-purified insulin receptors from both tissues.

\section{RESULTS AND DISCUSSION}

Insulin binding to liver and skeletal muscle receptor preparations was approximately 2 fold higher in fasted rats compared with fed rats. According to Scatchard's analysis, the enhanced insulin binding in both liver and skeletal muscle of fasted rats appeared to be due to an increase in the number of insulin binding sites (liver : $89 \pm$ 7 vs $46 \pm 2$ pmols/mg protein; muscle : 61 \pm 7 vs $36 \pm 6$ in fasted and fed group, respectively; mean \pm SEM) without any change in binding affinity. Improvement of insulin binding to both tissues from fasted rats appeared to agree with the increased insulin binding previously described in liver plasma membranes, hepatocytes, or isolated soleus of fasted rodents (Almira \& Reddy, 1979; Herrera et al., 1981; Brady et al., 1981; Le Marchand-Brustel \& Freychet, 1979). These increases correlated with the decrease in plasma insulin generally observed in fasted rats (Penicaud et al., 1985).

In liver, insulin-stimulated tyrosine kinase activity decreased significantly in fasted rats when compared to fed rats, whereas, basal activity was unchanged (Table I). Thus, the ability of insulin to stimulate the insulin receptor tyrosine kinase was greatly depressed during starvation. Contrary to liver activity, both basal and insulin stimulated kinase activity of muscle insulin receptors were unchanged in fasted and fed rats (Table I). Insulin sensitivity (determined as the insulin concentration required for $50 \%$ maximal stimulation) was not affected by nutritional state in both tissues.

The increased insulin binding sites, in both liver and skeletal muscle, could explain the apparent improved insulin sensitivity on hepatic glucose production or peripheral glucose utilization observed in vivo in fasted rats (Penicaud et al., 1985). In addition, our results confirmed that fasting altered the insulin receptor kinase activity in liver (Freidenberg et al., 1985; Simon et al., 1986). Such modification was consist- 
Table I. Insulin receptor tyrosine kinase activity in liver and skeletal muscle from fasted and fed rats.

\begin{tabular}{|c|c|c|c|c|}
\hline & \multicolumn{2}{|c|}{ Liver } & \multicolumn{2}{|c|}{ Muscle } \\
\hline & Fed & Fasted & Fed & Fasted \\
\hline $\begin{array}{l}\text { Basal activity } \\
\text { Maximal insulin }\end{array}$ & $\begin{array}{r}2.7 \pm 0.4 \\
33.6 \pm 5.7\end{array}$ & $\begin{array}{c}1.6 \pm 0.3 \\
14.8 \pm 2.8^{*}\end{array}$ & $\begin{array}{r}20 \pm 4 \\
113 \pm 19\end{array}$ & $\begin{array}{r}25 \pm 6 \\
102 \pm 13\end{array}$ \\
\hline
\end{tabular}

Values are means \pm SE of five individual experiments. They are expressed as fmoles ${ }^{32} \mathrm{P}$ incorporated/mg substrate/ min/pmole binding capacity. * $P<0.05$.

ent with the insulin unresponsiveness observed in vivo (Penicaud et al., 1985) or in vitro (Cech et al., 1980) in fasted rats. In skeletal muscle, normal insulin receptor tyrosine kinase during starvation supports the concept that the same metabolic change did not necessarily induce the same alterations of insulin receptor tyrosine kinase activity in different tissues.

\section{REFERENCES}

Almira E.C. \& Reddy W.J. (1979) Effect of fasting on insulin binding to hepatocytes and liver plasma membranes from rats. Endocrinology 104, 205-211

Brady L.J., Goodman M.N., Kalish F.N. \& Ruderman N.B. (1981) Insulin binding and sensitivity in rat skeletal muscle : effect of starvation. Am. J. Physiol. 240, E184-E190

Cech J.M., Freeman R.B., Caro J.F. \& Amatruda J.M. (1980) Insulin action and binding in isolated hepatocytes from fasted, streptozotocindiabetic and older spontaneously obeses rats. Biochem. J. 188, 839-845

Freidenberg G.R., Klein H.H., Cordera R. \& Olefsky J.M. (1985) Insulin receptor kinase ac- tivity in rat liver. Regulation by fasting and high carbohydrate feeding. J. Biol. Chem. 260, 12444-12453

Havrankova J., Roth J. \& Browstein M.J. (1978) Insulin receptors are widely distributed in the central nervous system of the rat. Nature 272, 827-829

Hedo J.A., Harrison L.C. \& Roth J. (1981) Binding of insulin receptors to lectins : evidence for common carbohydrate determinants on several membrane receptors. Biochemistry 20, 33853393

Herrera M.T., Prieto J.C., Guerrero J.M. \& Goberna R. (1981) Effects of fasting and refeeding on insulin binding to liver plasma membranes and hepatocytes from normal rats. Horm. Metab. Res. 13, 441-445

Le Marchand-Brustel Y. \& Freychet P. (1979) Effect of fasting and streptozotocin diabetes on insulin binding and action in the isolated mouse soleus muscle. J. Clin. Invest. 64, 1505-1515

Penicaud L., Kande J., Le Magnen J. \& Girard J.R. (†985) Insulin action during fasting and refeeding in rat determined by euglycemic clamp. Am. J. Physiol. 249, E514-E518

Simon J., Rosebrough R.W., McMurtry J.P., Steele N.C., Roth J., Adamo M. \& Leroith D. (1986) Fasting and refeeding alter the insulin receptor tyrosine kinase in chicken liver but fail to affect brain insulin receptors. J. Biol. Chem. $261,17081-17088$ 